\title{
Synthesis of some butenolides and study of their antibacterial activity
}

\author{
Noureddine Tamma*, Noureddine Gherraf \\ Laboratoire de Valorisation et Technologie des Ressources Sahariennes, \\ Département Sciences de la Matière, Institut des Sciences et Technologie, \\ Centre Universitaire d'El-Oued, B.P. 789 El-Oued 39000, Algerie \\ *E-mail address: noureddine.tamma@gmail.com
}

\begin{abstract}
Butenolides and their analogues represent a wide range of natural compounds of a medical and biological importance. In the last decades, a great number of compounds of various structures, in general from Alkylidene butenolide, were isolated and showed biological activities. In this work we have studied the reactivity of some alkylidene butenolide and their antibacterial activity. the study is of a scientific interest in terms of the synthesis of new compounds (Butenolide 01: 5-hydroxy-5-(1methoxypropan-2-yl)-4-methylfuran-2(5H)-one, Butenolide 02: 5-(1-methoxypropan-2-yl)-4methylfuran-2(5H)-one) that have not been studied before by other researchers; and of an economic importance because of its synthesis process which is easy and inexpensive. Moreover, butenolide showed a positive antimicrobial activity (antibiotic) against pathogenic bacteria (mainly Enterobacter hafniae).
\end{abstract}

Keywords: Butenolides; addition 1,6 reagents organocuprates; biological activity

\section{INTRODUCTION}

In recent years, there has been a great interest in preparing butenolides [1-8] containing compounds due to the biological effects attributed to this class of natural products such as freelingyne, rubrolides, etrenolin-furanosesquiterpenoid, Protoanemonin [9-11]. Among these bioactive compounds, there exist the alkylidenes butenolides, which have a large spectrum of biological activity [12-17].

\section{EXPERIMENTAL SECTION}

\section{1. Preparation of Lactones}

We have been interested in the preparation of some alkylidene butenolides using the method previously developed in our laboratory. In fact the method deals with the cycliztation of $\beta$--iodide- $\alpha, \beta$-unsaturated acids using an alkynes with the presence of potassium carbonate and copper iodide, for this purpose we have used a type of alkynes. 


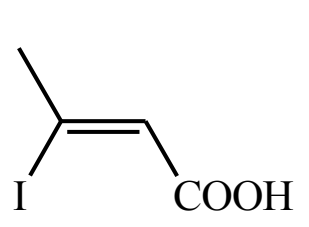

Acid

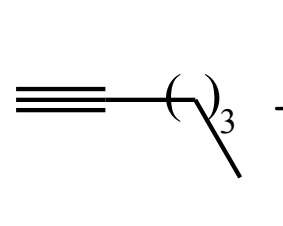

$8 \mathrm{H}$ in DMF

Alkyne

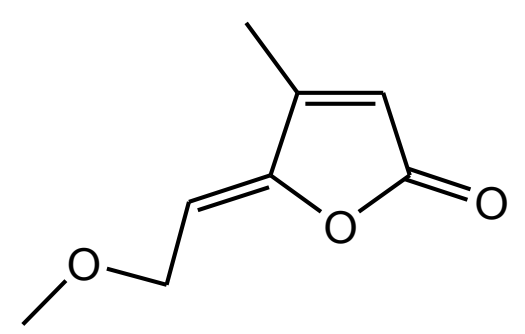

Lactone

$60 \%$

We noticed that very poor yields were obtained with (Z)-3-iodoacrylic acid. On the other side, good yields were found with (Z)-3-iodobut-2-enoic acid. Hence, we opted to work on this acid.

Reactions with hexyne and octyne gave rise to two isomers: a furanone and a pyranone contrarily to other types of alkyne that produced only furanone.

Under a nitrogen atmosphere the iodide acid was added to a stirred solution of calcium carbonate (2eq) in DMF, the resulting mixture was cooled down to $-80{ }^{\circ} \mathrm{C}$ for 10 minutes and then warmed up to room temperature. After that, the alkyne (1,5 eq) and the copper iodide (0.2 eq) were added respectively under nitrogen flux. Heating to $80^{\circ} \mathrm{C}$ and stirring overnight the solution, it was cooled to $\mathrm{rt}$ and quenched with saturated aqueous solution of $\mathrm{NH}_{4} \mathrm{Cl}$ before being extracted three times with AcOEt. The combined organic layers were washed with saturated brine, dried over anhydrous $\mathrm{MgSO}_{4}$ and then concentrated in vacuo. The residual oils were purified by flash chromatography using an eluent system of petroleum ether/ether to give the corresponding lactones.

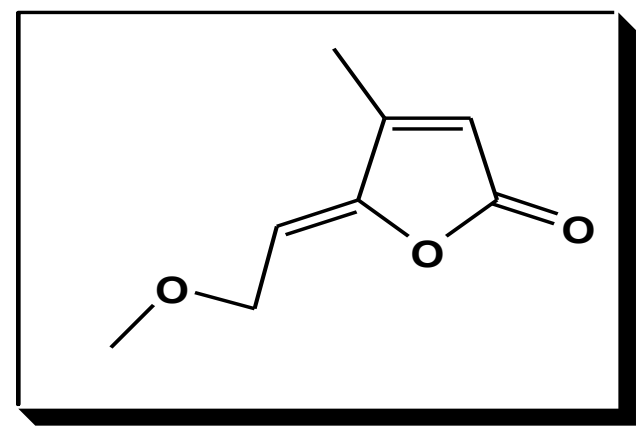

(Z)-5-(2-methoxyethylidene)-4-methylfuran-2(5H)-one

$\mathrm{RMN}{ }^{1} \mathrm{H}\left(300 \mathrm{MHz}, \mathrm{CDCl}_{3}\right): \delta=2.16(\mathrm{~s}, 3 \mathrm{H}), 3.39(\mathrm{~s}, 3 \mathrm{H}), 4.29(\mathrm{~d}, J=6.80 \mathrm{~Hz}, 2 \mathrm{H})$, $5.41(\mathrm{t}, J=6.80 \mathrm{~Hz}, 1 \mathrm{H}), 5.98(\mathrm{~s}, 1 \mathrm{H})$.

$\mathrm{RMN}{ }^{13} \mathrm{C}\left(75 \mathrm{MHz}, \mathrm{CDCl}_{3}\right): \delta=12.16(1 \mathrm{C}), 58.96(1 \mathrm{C}), 66.87(1 \mathrm{C}), 108.30(1 \mathrm{C}), 117.81(1 \mathrm{C})$, 150.63(1C), 154.74(1C), 169.48(1C).

\section{2. Addition of organocuprates}

Once the lactones were in hand, the next step consisted in carrying out the organocuprate addition using copper iodide. For this operation, the prescribed method is to 
add the methyllithium on copper iodide in anhydrous ether at $-5{ }^{\circ} \mathrm{C}$. Then, the lactone is added dropwise via canola before being quenched with $\mathrm{NH}_{4} \mathrm{Cl} / \mathrm{NH}_{4} \mathrm{OH}(90 / 10)$ at $0{ }^{\circ} \mathrm{C}$ and warmed till r.t. This method revealed the presence of two isomers as shown below:<smiles>COC/C=C1\OC(=O)C=C1C</smiles>

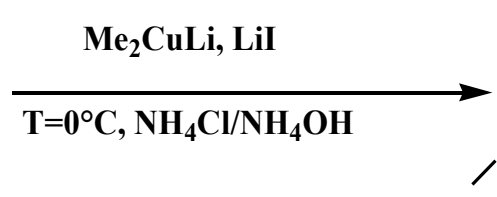<smiles>COCC(C)C1(O)OC(=O)C=C1C</smiles><smiles>COCC(C)C1OC(=O)C=C1C</smiles>

Butenolide 01 Butenolide 02 total yield $46 \%(74: 46)$

To improve the total output, the idea was to replace the copper iodide by other copper salts such as copper cyanide. Nevertheless, there was almost no enhancement even by adding $\mathrm{TMSCl}$ as an accelerator.

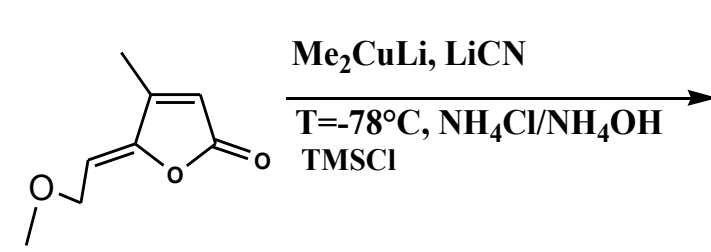

Butenolide 01<smiles>COCC(C)C1(O)OC(=O)C=C1C</smiles>

$+$<smiles>COCC(C)C1OC(=O)C=C1C</smiles>

Butenolide 02

$$
\rho<50 \%
$$

Butenolide 01: 5-hydroxy-5-(1-methoxypropan-2-yl)-4-methylfuran-2(5H)-one Butenolide 02 : 5-(1-methoxypropan-2-yl)-4-methylfuran-2(5H)-one

\subsection{The biological activity of compounds}

After the preparation of derivatives Alkylidene Butenolide, different amounts of Betenolides has been melted (dissolved) in an organic solvent (di-ethylether) in three different concentrations and injected into the discs. Then, the solvent is evaporated through a dryer in a temperature less than $37^{\circ} \mathrm{C}$.

To study the antibacterial properties of Butenolide, we used three types of bacteria affecting human health, these bacteria are:

\section{Bacteria strains}

E. coli a Gram-negative bacteria found in the lower intestine of some annimals (endotherms). Most E. coli strains are harmless, but some serotypes can cause serious food poisoning in humans. 
Proteus mirabilis is a Gram-negative bacteria, facultatively anaerobic. $P$. mirabilis causes 90 $\%$ of all Proteus infections in humans.

Enterobacter hafniae: gram negative bacteria, commensal of the human gastrointestinal tract and not pathogenic, but may cause diseases.

These bacteria were cultivated at the Mohamed Boudhiaf Hospital in Ouargla. After the preparation of Mueller Hinton culture medium, it is poured into the Petri dishes $(20 \mathrm{ml} / \mathrm{dish})$, then it is spread uniformly in the trays and dried in the oven for $20 \mathrm{~min}$ to remove the excess of moisture we cut disks of blotting paper of $6 \mathrm{~mm}$ diameters, and then put them in a test tube for sterilization in the oven at a temperature of $120^{\circ} \mathrm{C}$ for a period of $30 \mathrm{~min}$.

Using platin tweezers we took samples of the target bacteria in a test tube containing $10 \mathrm{ml}$ of $\mathrm{NaCl}$. Then pour $01 \mathrm{ml}$ of suspension in each Petri dishes and spread it using tug reaching the edges. Finally the dishes are left in the incubator for $15 \mathrm{~d}$ at a temperature of $37^{\circ} \mathrm{C}$.

We put the sterilized disks in Petri dishes containing the microbial suspension (06 disks per pack of $10 \mathrm{~cm}$ ), at equal distances. Then, the disks are injected with different concentrations of the chosen antibiotic. After that, the dishes are left in the incubator for 24 hours at a temperature of $37^{\circ} \mathrm{C}$.

\section{4. The treatment with the antibiotic}

The study was carried to find The Minimum Inhibitory Concentration (MIC) which is the lowest concentration of antibiotic to inhibit (bacteriostasis) fully bacterial growth after 18 to 24 contact hours at $37^{\circ} \mathrm{C}$. The most important ways to treat bacteria is diffusion.

The diffusion method is the most commonly used. It consisted in the use of Miller Hinton culture medium in order to determine the resistance or sensitivity of some harmful species of bacteria to antibiotics.

The groups of bacteria are as follows:

- (S) Sensitive to the antibiotic: $\mathbf{c}>$ MIC

- (R) Resistant to the antibiotic: $\mathbf{C}<$ MIC

- (I) Intermediate sensitivity to the antibiotic if the concentration is $\mathbf{c}>\mathbf{M I C}>\mathbf{C}$ where:

$\mathbf{C}$ is the Top critical concentration of the antibiotic in which the effectiveness is weak. $\mathbf{c}$ is the lesser critical concentration of the antibiotic with a large effectiveness .

\section{RESULTS AND DISCUSSION}

The results are read by the measurement of inhibition diameter around the disk. We injected three different concentrations of each compound in Petri dishes containing $E$. coli. After, 24 hours of incubation, we measured the diameter of the repression area in the dishes. We repeated the process many times to check the results. This same process was done with the other bacteria. The results are recorded in Table 1. 
Table 1. The diameter changes of repression area function to antibiotic concentration.

\begin{tabular}{|c|c|c|c|c|}
\hline \multirow[b]{2}{*}{ Compound } & \multirow[b]{2}{*}{$\begin{array}{c}\text { Concentratio } \\
\mathbf{n}(\mu \mathrm{g} / \mathrm{ml})\end{array}$} & \multicolumn{3}{|c|}{ Inhibition zone diameter (mm) } \\
\hline & & $\begin{array}{l}\text { Escherichia } \\
\text { coli }\end{array}$ & $\begin{array}{c}\text { Proteus } \\
\text { mirabilis }\end{array}$ & $\begin{array}{c}\text { Enterobacter } \\
\text { hafniae }\end{array}$ \\
\hline \multirow{3}{*}{$\begin{array}{c}\text { Butenolide } \\
01\end{array}$} & 0.073 & - & - & 20 \\
\hline & 0.042 & - & - & 18 \\
\hline & 0.015 & - & - & 13 \\
\hline \multirow{3}{*}{$\begin{array}{l}\text { Butenolide } \\
\quad 02\end{array}$} & 0.073 & - & - & 21 \\
\hline & 0.042 & - & - & 10 \\
\hline & 0.015 & - & - & 09 \\
\hline
\end{tabular}

The effect of the compounds on Proteus mirabilis and Escherichia coli: the inhibition diameter is nil with all the concentrations of the compounds. Therefore, we can say that the bacteria did not show any sensitivity towards Butenolide.

The effect of the compounds on Enterobacter hafniae:

Butenolide 01:

- At 0.073 and $0.042 \mu \mathrm{g} / \mathrm{ml}$; The inhibition diameters were 20 and $18 \mathrm{~mm}$ respectively, as a result, we can say that the bacterium Enterobacter hafniae has a medium sensitivity to this compound.

- At $0.015 \mu \mathrm{g} / \mathrm{ml}$; the inhibition diameter marked $13 \mathrm{~mm}$ showing a resistance of the Enterobacter Hafniae towards it.

Butenolide 02:

- At 0.073 and; inhibition diameter was $21 \mathrm{~mm}$. We can say that the bacterium Enterobacter hafniae is sensitive to it.

- At $0.042 \mu \mathrm{g} / \mathrm{ml}$. and $0.015 \mu \mathrm{g} / \mathrm{ml}$; the inhibition diameter marked $10 \mathrm{~mm}$ and $9 \mathrm{~mm}$, respectively,the bacteria showed a resistance to Butenolide 2 .

Figure 1 shows clearly the inhibition diameters of the compounds that gave positive results with Butenolides

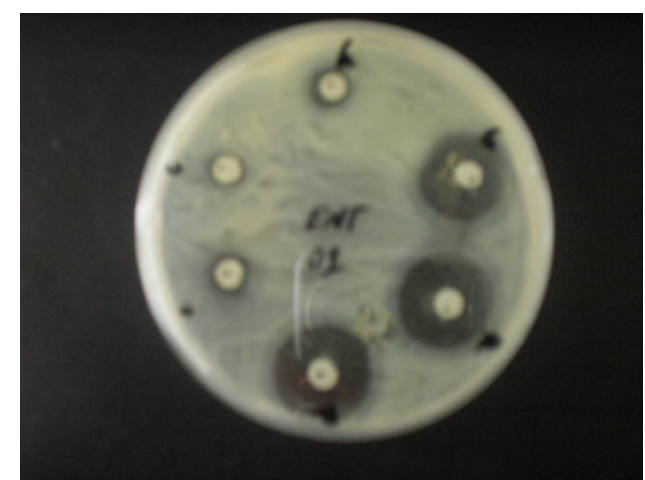

A.B. of Butenolide 01

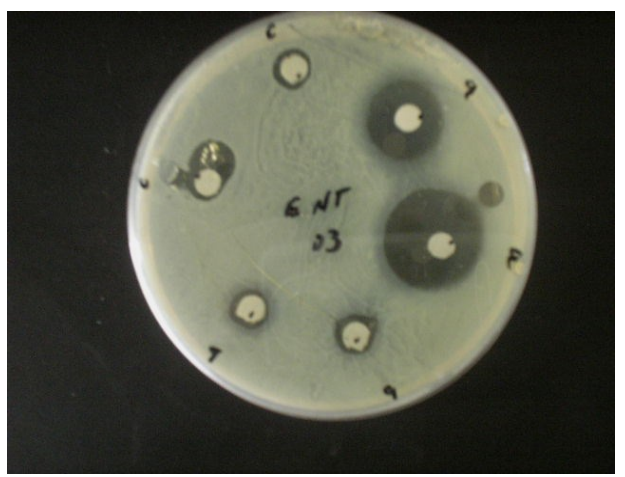

A.B. of Butenolide 02

Figure 1. The impact of the Butenolide derivatives on Enterobacter hafniae. 
Through the results obtained in the previous study, we can determine the sensitivity of each type of bacteria to various concentrations of each compound Table 2 illustrates this details.

Table 2. Comparison of the biological activity of the compounds on the types of the selected bacteria.

\begin{tabular}{|c|c|c|c|}
\hline \multirow{2}{*}{ Bacteria } & \multicolumn{3}{|c|}{ The degree of sensitivity of the bacteria } \\
\cline { 2 - 4 } Compounds & Enterobacter hafniae & Proteus mirabilis & Escherichia coli \\
\hline Butenolide 01 & $\mathrm{I}$ & - & - \\
\hline Butenolide 02 & $\mathrm{~S}$ & - & - \\
\hline
\end{tabular}

\section{CONCLUSION}

According to the results obtained, we can determine the sensibility of each bacteria towards each compound .

According to the obtained results we can deduce :

- The derivative are obtained by adding organocupper reagent to butenolides at the position-1.6.

- The obtained butenolides from the addition-1.6 are new compounds .

- Most of the steps of reaction are simple and economical.

- The Chemical compound 5-(1-methoxypropan-2-yl)-4-methylfuran-2(5H)-one gave positive results against Enterobacter hafniae.

\section{References}

[1] Xu C., Negishi E., Tetrahedron Lett. 40 (1999) 431.

[2] Ma S., Shi Z., J. Org. Chem. 63 (1998) 6387.

[3] Rossi R., Bellina F., Biagetti M., Mannina L., Tetrahedron Lett. 39 (1998) 7799.

[4] Rossi R., Bellina F., Biagetti M., Mannina L., Tetrahedron Lett. 39 (1998) 7599.

[5] Rossi R., Bellina F., Mannina L., Tetrahedron Lett. 39 (1998) 3017.

[6] Rossi R., Bellina F., Bechini C., Mannina L., Verganini P., Tetrahedron 54 (1998) 135.

[7] Liu F., Negishi E., J. Org. Chem. 62 (1997) 8591.

[8] Marshall J. A., Wolf M. A., Wallace E. M., J. Org. Chem. 62 (1997) 367.

[9] Rao Y. S., Chem. Rev. 76 (1976) 625.

[10] Rao Y. S., Chem. Rev. 64 (1964) 353. 
[11] Negishi E., Kotora M., Tetrahedron 53 (1997) 6707.

[12] Von der Ohe F., Brückner R., Tetrahedron Lett. 39 (1998) 1909-1910.

[13] Jorgensen J. H., Ferraro M., J. Clin. Infect. Dis. 26 (1998) 973-980 .

[14] Robert-Dernuet S., (Editeur: Décarie Vigot), Antibiotiques et antibiogrammes, Montréal, Paris 1995, p. 322.

[15] Ericsson H. M. O., Sherris. J. C., Antibiotic Sensitivity Testing, Report of an International Collaborative Study. -Actes. path. Microbiol. Scand., B Suppl., 1971, pp. 90, 217.

[16] Baurer A. W., Kirry W. M. M., Sherries J. C. A., Turch M., Amer J. Clin. Pathol. 45 (1966) 493-496.

[17] L'antibiogramme: Principes, Méthodologie, Intérêt et Limites. Journées nationales GVT-INRA Guerin Faublée V., Carret C., 1999, pp. 5-12 . 